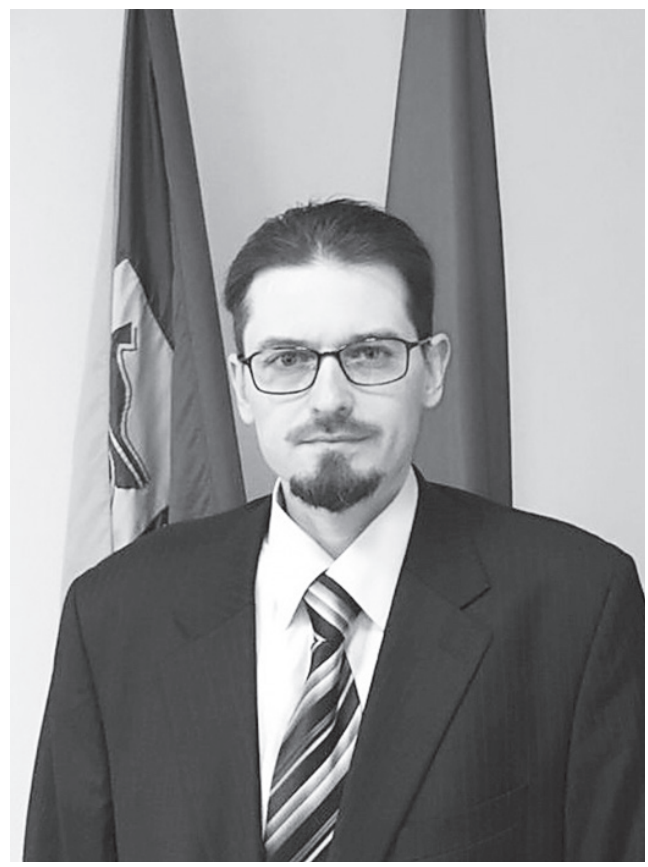

УДК: 378.014 (477)

DOI: https://doi.org/10.32689/2617-

2224-2019-17-2-188-199

Мартишин Денис Сергійович,

кандидат наук з богослов'я, завідувач кафедри українознавства, православ'я та теології, Міжрегіональна Академія управління персоналом, 03039, м. Київ, вул. Фрометівська, 2, тел.: (098) 56165 63, е-таil: mdsdenim@ukr.net

ORCID: 0000-0002-2770-7757

Мартышин Денис Сергеевич, кандидат наук по богословию, заведующий кафедрой украиноведения, православия и теологии, Межрегиональная Академия управления персоналом, 03039, 2. Киев, ул. Фрометовская, 2, тел.: (098) 56165 63,e-mail:mdsdenim@ukr.net

ORCID: 0000-0002-2770-7757

Martyshyn Denys Serhiiovych,

candidate sciences in theology, Associate Professor, head of the Department of Ukrainian Studies, Orthodoxy and Theology, Interregional Academy of Personnel Management, 03039, Kyiz, Str. Frometivska, 2, tel.: (098) 56165 63,e-mail:mdsdenim@ukr.net

ORCID: 0000-0002-2770-7757

\title{
РОЛЬ ПРАВОСЛАВНОЇ ЦЕРКВИ УКРАЇНИ В СУЧАСНИХ ПРОЦЕСАХ ДЕРЖАВОТВОРЕННЯ
}

Анотація. Висвітлено роль Православної Церкви України у зміцненні процесів державності та єднання українського народу у контексті політичних, економічних та культурних змін у житті України. Проаналізовано реальні проблеми та можливі шляхи духовного єднання українського народу, а також головні аспекти державотворення у вітчизняній богословській і політологічній думці. Обгрунтовано, що діалог Української Християнської Церкви та суспільства постійно буде базисним елементом суспільного розвитку та платформою процесів демократизації в Україні.

3 точки зору соціального вчення церкви, можна дійти висновку, що самоорганізаційні духовні та соціальні процеси, які відбуваються на рівні церковних парафій горизонтальних зв'язків, ефективно впливають на розвиток процесів державотворення та громадянського суспільства в Україні. Зважаючи на ситуацію загалом, виникає потреба переглянути позиції щодо напрямів подальшого розвитку діалогу церкви та держави у процесі державотворен- 
ня, акцентуючи увагу на мотивації самоорганізаційних процесів в управлінні на рівні церковних громад, на потенційних можливостях співпраці інститутів церкви, держави та громадянського суспільства в духовній, культурній, освітній сферах, на досягненні паритету на рівні вертикально-горизонтальних зв’язків з метою збалансування інтересів суб’єкта та об'єкта державного управління.

Визначено, що для налагодження тісних взаємовідносин держави і церкви у процесах державотворення в управлінні потрібна не локальна і не фрагментарна, а постійна та стійка суспільна самоорганізація церковних парафій (соціальне служіння, освіта, виховання, проповідь, спілкування) у поєднанні з ефективним державним управлінням. Слід також зважити на ту обставину, що на рівні церковного життя Православної Церкви України та формування соціального вчення церкви потрібно сформувати загальне уявлення щодо подальшого розвитку взаємовідносин держави та церкви в управлінні.

Ключові слова: держава, християнство, взаємодія, діалог, соборність, єдність, політика, глобалізація, економіка, демократія, модернізація.

\section{РОЛЬ ПРАВОСЛАВНОЙ ЦЕРКВИ УКРАИНЫ В СОВРЕМЕННЫХ ПРОЦЕССАХ ГОСУДАРСТВЕННОГО СТРОИТЕЛЬСТВА}

Аннотация. Показана роль Православной Церкви Украины в укреплении современных процессов государственного строительства и единства украинского народа в контексте политических, экономических и культурных изменений в жизни Украины. Проанализированы реальные проблемы и возможные пути духовного единства украинского народа, а также главные аспекты государственного строительства в отечественной богословской и политологической мысли. Обосновано, что диалог Украинской Христианской Церкви и общества постоянно будет базисным элементом общественного развития и платформой процессов демократизации в Украине.

С точки зрения социального учения церкви, можно прийти к заключению, что самостоятельные организационные духовные и социальные процессы, которые происходят на уровне церковных приходов горизонтальных связей, эффективно влияют на развитие процессов создания государства и всего гражданского общества в Украине. Принимая во внимание ситуацию в целом, возникает потребность пересмотреть позиции относительно направлений дальнейшего развития диалога церкви и государства в процессе создания государства, акцентируя внимание на мотивации самостоятельных организационных процессов в управлении на уровне церковных общин, на потенциальных возможностях сотрудничества институтов церкви, государства и гражданского общества в духовной, культурной, образовательной сферах, на достижении паритета на уровне вертикально-горизонтальных связей с целью балансирования интересов субъекта и объекта государственного управления.

Обозначено, что для налаживания тесных взаимоотношений государства и церкви в процессах создания государства в управлении нужна не локаль- 
ная и не фрагментарная, а постоянная и стойкая общественная самоорганизация церковных приходов (социальное служение, образование, воспитание, проповедь, общение) в сочетании с эффективным государственным управлением. Следует также обратить внимание на то обстоятельство, что на уровне церковной жизни Православной Церкви Украины и формирования социального учения церкви необходимо сформировать общие представления относительно дальнейшего развития взаимоотношений государства и церкви в управлении.

Ключевые слова: государство, христианство, взаимодействие, диалог, соборность, единство, политика, глобализация, демократия, модернизация.

\section{THE ROLE OF THE ORTHODOX CHURCH OF UKRAINE IN THE CURRENT PROCESSES OF STATE FORMATION}

Abstract. The article shows the role of the Orthodox Church of Ukraine in strengthening the processes of statehood and unity of the Ukrainian people in the context of political, economic and cultural changes in the life of Ukraine. The real problems and possible ways of spiritual unity of the Ukrainian people are analyzed, as well as the main aspects of state formation in the national theological and political thought. It is substantiated that the dialogue between the Ukrainian Christian Churches and society will always be the basic element of social development and the platform of democratization processes in Ukraine.

From the point of view of the social doctrine of the Church we can conclude that the self-organizing spiritual and social processes that take place at the level of church parishes of horizontal ties effectively influence the development of the processes of state formation and the whole civil society in Ukraine. Taking into account the situation as a whole, there is a need to reconsider the positions regarding the further development of the dialogue between the Church and the state in the process of state building, focusing on the motivation of self-organization processes in governance at the level of church communities, potential opportunities for cooperation between the institutes of the Church, state and civil society in the spiritual, educational spheres, achieving parity at the level of vertical-horizontal ties in order to balance: the interests of the subject and the object of public administration.

The author is convinced that in order to establish close relations between the state and the Church in the processes of state formation in management it is necessary not local and not fragmentary but constant and steady social selforganization of church parishes (social service, education, upbringing, preaching, communication) in conjunction with an effective state management. It should also take into account the fact that at the level of the church life of the Orthodox Church of Ukraine and the formation of the social doctrine of the Church it is necessary to form a general idea of the further development of relations between the state and the Church in management.

Keywords: state, Christianity, interaction, dialogue, unity, politics, globalization, economy, democracy, modernization. 
Постановка проблеми. Суспільний розвиток на порозі XXI ст. супроводжується глобальними змінами у сферах, які визначають умови життя людей на глобальному та національному рівнях. Усе більше церковних діячів, вчених, політиків, державних управлінців зазначають, що потрібно поглиблювати діалог церкви та держави, активно залучаючи віруючих людей до процесів державотворення. Питання пошуку конструктивної взаємодії церкви і держави ніколи не втрачають своєї актуальності. Збереження і розвиток української державності та демократичного громадянського суспільства неможливі без опори на духовно-моральні цінності сучасного християнства, що освячувало церковно-державні відносини впродовж багатовікової історії українського народу. Саме християнство стало основою духовної культури України. Тому сьогодні серед чисельних вагомих державницьких рішень особливе місце посідають процеси державотворення, зміцнення безпеки життя суспільства у діалозі з релігійними організаціями. Взаємодія церкви та держави стане запорукою зміцнення української державності, стабільності в суспільному житті, релігійної, культурної та історичної спадщини для наступних поколінь.

Відомо, що Українська Православна Церква (УПЦ); Українська православна церква Київського патріархату (УПЦ КП); Українська автокефальна нравославна церква (УАПЦ), пройшовши довгий шлях подолання розколу з благословення Апостольського Константинопольського Престолу та Всесвятішого Патріарха Вселенського Варфоло- мія (Архондоніса) 15 грудня 2018 р. створили нову об'єднану автокефальну Православну Церкву України (ПЦУ), обравши нового Предстоятеля - Блаженнішого Митрополита Київського і всієї України Епіфанія. Православна церква України 6 січня 2019 р. отримала від Вселенського Престолу томос про автокефалію.

Аналіз останніх публікацій за проблематикою. Вивчаючи велику кількість наукових монографій, богословських джерел, різноманітних статей з питань державотворення, духовного єднання українського народу, стає зрозумілим, що це актуалізує потребу в науково-богословському і світському діалозі 3 питань розбудови держави та нації. Науковою розробкою цієї проблеми займалися як зарубіжні (М. Вебер, Р. Нібур, Н. Райт, А. Сторкі, Т. Бремер, Г. Кюнг, Д. Карсон та ін.), так і вітчизняні дослідники (К. Говорун, В. Бедь, М. Маринович, П. Толочко, В. Лубський, П. Яроцький, А. Колодний, В. Бондаренко, Л. Филипович, Ю. Чорноморець, В. Сленський, А. Деркач, В. Кириленко, О. Саган, О. Шуба, М. Пірен, М. Палінчак, В. Бебик, В. Петренко, М. Черенков, А. Зінченко, Ю. Кальниш, С. Плохій, О. Субтельний, В. Ульяновський, М. Кудряков, І. Ісіченко, О. Драбинко, І. Мацелюх, С. Головін, І. Значков).

В останні десятиріччя проблематика державотворення, єдності Українського Православ'я привертає особливу увагу церковних діячів і багатьох світських науковців. Але на сьогодні комплексних досліджень, присвячених розгляду процесів конструктивного діалогу держави та 
церкви, духовного державотворення у сфері державного управління практично немає. Треба зазначити, що на сьогодні бракує фундаментальних i спеціальних наукових праць 3 державного управління, які були б присвячені богословському аналізу багатогранного процесу взаємовідносин між Українськими Християнськими Церквами і Українською державою.

Постановка завдання. Метою статті є вирішення науково-теоретичного завдання, що полягає в розкритті ролі Православної Церкви України у сучасних процесах державотворення та пошуку шляхів духовного єднання українського народу.

Мета дослідження зумовила постановку і розв'язання таких завдань:

- схарактеризувати процес становлення та розвитку основних напрямів взаємодії державної влади та Православної Церкви України у процесах державотворення;

- розкрити шляхи духовного єднання українського народу;

- запропонувати шляхи вдосконалення основних напрямів взаємодії Української держави та Українських Християнських Церков.

Виклад основного матеріалу. Вiдомо, що духовне й культурне відродження в посттоталітарних країнах стало можливим лише після ліквідації безбожного комуністичного режиму, коли волелюбний український народ обрав демократичну форму устрою життя. Незважаючи на невдалі економічні реформи, політичну маніпуляцію, всеохоплюючу корупцію, суспільство пробудилося від комуністичного застою до громадянської активності. Людина почала цікавитися питаннями духовної культури, релігії, теологіï, філософії, прав та свобод, підприємницької діяльності, модернізації та проблемами трансформації суспільної свідомості.

Неважко помітити, що незаперечно зросла роль релігійних інститутів у перетворенні всіх аспектів життя посттоталітарних країн колишнього Радянського Союзу. Якщо в радянському суспільстві релігійне життя було обмеженим, орієнтованим виключно на внутрішні духовні питання християнського життя та храмового богослужіння, то 3 настанням демократичних реформ релігія стала вагомою у формуванні процесів державотворення й розбудови громадянського суспільства.

Релігійні громади намагаються стати гармонійною інтегральною частиною української держави, суспільства, визнаною духовно-моральною силою, що має високий суспільний авторитет. Вперше після багатьох століть Українські Християнські Церкви набули права самостійно, без втручання з боку світської влади, визначати своє місце у суспільстві, вибудовувати свої стосунки 3 державою i громадянським суспільством. Кардинальні перетворення в українській державі, суспільно-політичні реформи, нові виклики сучасного світу створюють нові умови для розбудови всебічного релігійного життя. Справді, дедалі помітніше активна позиція священнослужителів. Вони активно залучаються до громадської дискусї з основних питань сучасності: державотворення, зміцнення національної безпеки держави, політики, економіки, бізнесу та формування громадян- 
ського суспільства. Нині в умовах реформування України принципового значення набуває реальний діалог між церквою, державою і громадянським суспільством. Прикладом цього є конструктивна співпраця держави з Всеукраїнською Радою Церков i релігійних організацій (ВРЦіРО) [1], яка є представницьким міжконфесійним консультативно-дорадчим органом і діє на громадських засадах. Членами Ради є релігійні центри діючих в Україні релігійних об'єднань (конфесій), статути яких зареєстровані у встановленому законодавством України порядку, представлені в Раді своїми керівниками.

Зрозуміло, що цей діалог пов’язаний з усіма складовими життя - політичною, релігійною, економічною, правовою, організаційною та іншими культурами. Завдання християнського богослов'я полягає в тому, щоб, проповідуючи про Бога, актуалізувати розуміння того, що релігійна віра несе в собі абсолютну правду про Бога, державу, людину, суспільство, політику, бізнес та виклики сучасної цивілізації.

I, нарешті, найважливіше. На нашу думку, однією з найбільш глобальних проблем сучасного українського суспільства є не лише війна, бідність та корупція, але й духовна ворожнеча. Змушені констатувати, що масштаб цієї проблеми в кінцевому підсумку наочно показує низький рівень соціальної та гуманітарної політики держави, просвітницького і соціального служіння християнських церков. Як не дивно, але сьогодні не вщухають наукові дискусії щодо національної ідеї, культури, мови богослужіння, церковної автокефалії, свободи релі- гійних громад та модернізації українського суспільства.

Точніше було б говорити про духовні засади української нації. Це цінності людської свободи, ідеали демократії, рух до модернізації, успіху, процвітання, соборності та порозуміння. Варто зрозуміти, що формування національної ідеї - не самоціль, а дієвий, практичний та конструктивний шлях до процвітання держави та всіх громадян України. Реалізація національної ідеї $є$ практичним намаганням створення такого соціального ладу, який би гармонізував інтереси всіх громадян України на принципах свободи, релігійного плюралізму, економічного процвітання, братнього порозуміння, толерантності, поваги, єдності та християнської любові.

Відомо, що християнська церква, що розбудовує власну духовну культуру, веде місіонерську діяльність, займається просвітництвом, здійснює це, насамперед, на основі власного духовного ідеалу, тобто в єдності буття з Живим Христом. I такий духовний ідеал не може бути сформульованим у відриві від духовного життя християнина з Богом, бути чимось штучно придуманим науковцями, політологами, іміджмейкерами i бажаним виключно для політиків. Мета церкви - перетворення життя людства у світлі Христової любові, навернення цілих народів в учнівство Христа, які звичайно мають право мати власну церкву і спроможні забезпечити повноцінне духовне життя сучасних демократичних країн. Саме за таких умов церковна автокефалія сповна виконує свою історичну місію i переростає у справжній духовний 
шлях до Бога. Хоча шлях віруючої людини до справжнього і повноцінного життя у Христі довготривалий i складний, ставати на нього треба все більш твердою і впевненою ходою вже нині, щодень, бо поки що, на наш погляд, йдемо досить хитко й невпевнено.

Зазначимо, що найвидатніша постать в житті Українського Православ'я другої половини $\mathrm{XX}-$ початку XXI ст. - Предстоятель Української Православної Церкви, Блаженніший Митрополит Київський і всієї України Володимир (Сабодан) (1935-2014), розмірковуючи про служіння Церкви, наголошував, що були часи, коли все вирішувала усна проповідь з церковного амвону. Але на сьогодні завданням сучасного богослова є як роз'яснення, так i розвиток соціального вчення церкви. "Сучасність потребує динамічного, але разом з тим глибокого, православного осмислення проблем життя суспільства. Православні богослови, враховуючи усі трансформації сучасного світу, мають сьогодні приділяти особливу увагу соціальній проблематиці, а церковні та світські засоби масової інформації надавати нашим богословам можливість донести свої думки та погляди суспільству" [2, с. 368-371]. Саме тому, на думку професора Юрія Чорноморця, впливовою в суспільстві є та Церква, яка має власні ініціативи для родини, сфери освіти, економіки та держави [3]. "У місцевій громаді християнське соціальне вчення бачить подобу родини, подобу парафії. Без живих місцевих громад, без самоврядування - неможливий здоровий соціальний організм нації. Правова держава зверху, соціальна солідарність знизу, забезпечення прав людини скрізь - ось три максими, які врятують Україну” [4].

Вочевидь, що українські церкви разом з українським суспільством шукають відповіді на низку найважливіших питань людського буття. Справедливості заради необхідно зазначити, що сьогодні не завжди легко священнослужителю та богослову відповідати на критику: "Чому Церква мовчить про те, що народ вимирає?" "Чому Україні бракує церковної єдності та порозуміння?” В якому соціумі ми живемо, яку державу будуємо, куди ми рухаємося, яке майбутнє матимуть наші діти, наскільки ми є далекими від справжніх християнських цінностей? Роздуми над цими питаннями мають складати основний зміст соціальної доктрини усіх християнських церков, політичної теології у діалозі з державним управлінням.

Відомо, що історія людства та церкви, зокрема, говорить про те, що побудувати міцну державу, подолати масову бідність, перемогти корупцію неможливо без дотримання закону, справедливої моделі високоефективної економіки і моральної відповідальності суспільства. Принципово важливо церкві говорити про місіонерство, просвіту, виховання, соціальну відповідальність церкви, держави, бізнесу, про справи милосердя та допомоги ближньому. Таким чином, у церкві має здійснюватися цілеспрямована постійна духовна й соціальна робота з суспільством. Ця робота передбачає формування соціальної активності парафіян у житті сучасного соціуму. Не лише світські 
науковці, а й церковні лідери змушені визнати, що сфера сучасної освіти, молодіжної та інформаційної політики найбільш сильно постраждали від хибної ізоляціоністської моделі розвитку парафіяльного життя.

Отже, особливо важливим бачиться співробітництво церкви та держави у впливі на духовне і культурне життя суспільства, яке включає мораль, культуру, мову, літературу, духовність, релігійні цінності людини, родини, трудового колективу. Еліта суспільства, держава, політичні партії, громадські та релігійні організації мають здійснювати профілактичну та виховну роботу із звуження соціальної бази деструкції, порушення прав людини, корупції тощо. Проблема визначення шляхів духовного єднання українського народу зумовлена, з одного боку, розумінням процесів державотворення, національної політики, геополітичних стратегій, а 3 іншого - адекватністю богословської рефлексії на виклики сучасної цивілізації, від яких значною мірою залежить майбутня місія християнства у світі.

Слід наголосити, що ідея духовного єднання українського народу затребувана в суспільстві, “оскільки існує об’єктивна необхідність самопізнання народом самого себе, своєї сутності, а відповідно, обгрунтування самоцінності та самозначимості свого існування" [5, с. 37]. Проте пошук духовної моделі розвитку України та іiі національної ідеї ускладнюється тим фактом, що сучасна людина надмірно обтяжена політичними маніпуляціями, ідеологізацією культури у контексті виключно матеріальних ціннісних орієнтирів розвитку люд- ства. Глобальне домінування фінансових інтересів, так звана філософія успіху, тотальна комерціалізація буття, на основі якої будується суспільне життя, знищує найважливіше потяг людини до духовної сфери, культури та релігії.

Наголосимо, що з точки зору християнства, живильної та дієвої форми національна ідея духовного розвитку українського суспільства набуває через призму християнських цінностей, які формують духовне підгрунтя релігійного, морально-духовного, культурного, історичного, національного, політичного і соціального буття в Українській державі та визначають духовні вектори орієнтації християнина. Слід також звернути увагу, що в історії людства Україна формувалися як своєрідна християнська демократична республіка.

Зрозуміло, ідеалізувати церковну сферу життя, у тому числі ставлення народу до церкви, християнських цінностей не доводиться. Але загалом церква, пам'ятаючи про власні недоліки, слабкості, інерцію, певну соціальну пасивність, намагається “достукатися” до свідомості, розуму народу, закликаючи його стати на шлях відповідальності перед Богом, державотворення, порозуміння, прощення, демократії та модернізації.

Відтак загрозливими були і є сьогодні для української нації не лише швидкі темпи руйнації принципів верховенства закону, спотворення судової системи, обмеження свободи слова, зневаги до людської гідності, а, насамперед, питання духовної цілісності, міцності та духовного єднання українського народу. Зазначимо, що психологія розколу, міфологізація 
історії [6], радянська ментальність, провінційне, селянське мислення деяких церковних ієрархів, політизація церковного життя, на основі якої політики вибудовують свої передвиборчі кампанії, обмежують найважливіше - здатність Христової Церкви нести радісну новину оновлення буття у єдності з Живим Богом, а також впроваджувати реальну силу соціальної та духовної трансформації усього людства.

На нашу думку, саме християнство займає особливе місце в концепції єднання українського народу, яке повинно реалізуватися у вигляді фактора стабілізації морального i етичного стану народу й держави. Вчення Христа освітлює різні формі людської діяльності - політику, культуру, економіку, мистецтво, літературу, живопис, журналістику. Запропонований богословський концепт єдності українського народу в принципі і по суті формує методологічну основу об'єднавчого базису консолідації різних конфесій в єдину гармонізовану соціальну спільноту - український народ $[2,9]$.

"Не ображаючи національних i релігійних почуттів інших народів, христологічна українська національна ідея ініціює духовні прагнення містичного пізнання Буття; повагу до людської особистості, етнічних i релігійних громад; установлення миролюбних зв'язків, заснованих на взаємопорозумінні народів” [5, c. 43]. Християнська ідея єдності характеризується відкритістю. Практично до неї можуть приєднатися всі конфесії України. Більше того, вона виходить із можливості свого сприйняття іншими народами на будь-яку глибину проникнення в сутнісну основу християнського віровчення. Не можна не погодитися 3 роздумами багатолітнього в’язня радянської табірної системи, сповідника Української Греко-Католицької Церкви, кардинала Йосифа Сліпого (1892-1984): “Брак почуття і розуміння єдності в основних питаннях життя Церкви і народу - це наше нещастя, це наш споконвічний гріх!” [7, с. 49]. "Наша загальна національна хиба - роз'єднування і розбивання, свари і чвари. Ми радо схліблюємо i коримося чужим, щоби могти суперничати між собою і шкодити рідній справі. Дав би Бог, щоб опам'яталися ми всі від гори до долу і думали про майбутнє добро України і 11 Церкви, щоб закинули свої амбіції і самсобіпанські бажання, і користі, а Бога й Україну висунули як провідну ідею нашого життя, думок і діл!” [7, с. 19].

Наголосимо, що єдність народу справді можна будувати лише на засадах соборності, плюралізму думок, свободи слова, національної злагоди, любові, прощення, поваги і толерантності - це незаперечна істина. Саме українські церкви мають робити все, аби український народ обминав будьякі міжнаціональні непорозуміння, провокації, ворожнечу, політичну маніпуляцію, а понад усе - воєнні конфлікти.

На нашу думку, досвід парафіяльного буття показує, що тільки орієнтація на власні шляхи розвитку, становлення і утвердження євангеліє може бути ефективною і спрямованою на реалізацію загальної вселенської священної місії християнської церкви. Тому з метою адаптації на- 
ціональних моделей катехізації, просвітництва, місіонерства до викликів сучасного світу важливим завданням є формування самодостатньої системи буття церковних громад, яка, попри єдність з усіма Православними Церквами світу, попри універсальну відкритість до всіх націй та народів, орієнтувалася на власну історію, ментальність, культуру та богословську традицію. "Українська богословська думка завжди концентрувала свою увагу на реальних проблемах людини, їі стражданнях, прагненнях та інтересах. Доля конкретної людини $є$ важливішою за питання кордонів імперії, геополітичних стратегій майбутнього світу. Державні, імперські інтереси завжди другорядні у порівнянні з питаннями християнської антропології.

Людська особистість - найвища цінність в очах Божих. Життя людства - у полоні політичних спекуляцій, тоталітарна модель розвитку суспільства руйнує саму людину, створену за образом та подобою Божою. Підкорення волі вільної людини шляхом партійних чвар, державних суперечностей, ідеологічних суперечностей інформаційною маніпуляцією якомусь земному зовнішньому авторитету, національному чи імперському, мусить розглядатися християнином як порушення Богом установленого устрою. Жити у любові, злагоді, повазі один до одного переконують нас, що це і є вічні, самоочевидні істини християнства. Сучасному православному християнинові важливо зруйнувати амбіційні імперські ідеологічні та вузьконаціональні шаблони сприйняття Православ'я" [8, с. 26].

\section{Висновки та перспективи подаль-} ших досліджень. Таким чином, існують усі передумови стверджувати, що державотворення та духовна ідея розвитку України, яка відповідає історії, культурі та ментальності українського народу, мусить базуватися на незмінній релігійній основі [9, c. 18]. Резюмуючи викладене, необхідно зазначити, що боротьба духовних ідей зосереджується в розумі й серці кожної людини [10, с. 126]. Християнство апелює саме до серця, розуму, свідомості, сумління кожної сучасної людини. Інакше кажучи, на сьогодні Православній Церкві України під керівництвом митрополита Епіфанія (Думенка) потрібно докласти чимало зусиль, щоб знову у серцях сучасників засяяло світло релігійної віри та запалав вогонь християнської надії. Лише тоді можна буде говорити про якісні перетворення у політиці, економіці та справжню модернізацію в українському соціумі.

Слід зазначити, що, досліджуючи релігійну культуру тієї чи іншої країни, науковцям, майбутнім державним службовцям треба пам'ятати про факт існування багатьох регіональних та національних варіацій релігійної культури. Вивчаючи церковну історію, психологію, культуру та ментальність українського народу, оцінюючи геополітичне положення України, враховуючи реальні прагнення церковних парафій до власної культурної та соціальної ідентичності, все нагальніше постає питання актуалізації особливостей та унікальностей релігій України. 


\section{СПИСОК ВИКОРИСТАНИХ ДЖЕРЕЛ}

1. Інформація про ВРЦіРО // Інтернетпортал "Всеукраїнська Рада Церков i релігійних організацій” [Електронний ресурс]. - 2016. Режим доступу: http://vrciro.org. ua/ua/council/info - Дата доступу: 12.05.2016.

2. Володимир (Сабодан), Митрополит Київський та всієї України. Доповіді, промови, звернення. - К.: Видав. відділ Української Православної Церкви, 2011. - 422 с.

3. Чорноморець Юрій. Ідеал Християнської України як вимога соціального вчення християнських Церков // Iнтернет-портал "РІСУ. Релігійно-інформаційна служба України” [Електронний ресурс]. - 2018. - Режим доступу: http://risu.org.ua/ua/index/ expert_thought/ analytic/47555/ Дата доступу: 25.12.2018.

4. Чорноморещь Юрій. Відповідальність Церков за майбутнє України // Інтернет-портал "РІСУ. Релігійно-інформаційна служба України" [Електронний ресурс]. - 2018. Режим доступу: http://risu.org. ua/ua/index/studios/materials conferences/56445/- Дата доступу: 25. 12. 2018.

5. Сталий розвиток: світоглядна ідеологія майбутнього: [монографія] / [M. А. Хвесик, I. К. Бистряков, Л. В. Левковська, В. В. Пилипів]; за ред. акад. НААН України М. А. Хвесика. - К.: Державна установа "Ін-т економіки природокористування та сталого розвитку Нац. акад. наук України”, 2012. - 465 с.

6. Головатий М. Ф. Політична міфологія: навч. посіб. - К.: МАУП, 2006. - $144 \mathrm{c}$.

7. 125 думок Патріярха Йосифа Сліпого / Упоряд. Тереза Ференц. Львів: Свічадо, 2017. - 144 с.
8. Мартишин Діонісій, прот. Зустріч із Живим Богом: духовні бесіди на православні свята / Д. Мартишин. К.: Духовно-просвітницький Центр імені Святих Апостолів, 2013. $104 \mathrm{c}$.

9. Віктор (Бедъ), архім. (Бедь В. В.). Конституційно-правові аспекти реалізації права людини на свободу совісті та віровизнання. - Ужгород: Інформаційно-видавничий центр “УУБА-КаУ”, 2010. - 278 с.

10. Мартишин Д. С. Діалог Української Православної Церкви та суспільства у процесі політичних трансформацій України: монографія / Д. С. Мартишин. - Київ: ДП “Вид. дім “Персонал”, 2017. - 272 с.

\section{REFERENCES}

1. Informatsiia pro VRTsiRO [Information about "All-Ukrainian Council of Churches and Religious Organizations"]. (2016). vrciro.org.ua. Retrieved from http://vrciro.org.ua/ua/ council/info [in Ukrainian].

2. Volodymyr (Sabodan), Metropolitan of Kiev and All Ukraine. (2011). Dopovidi, promovy, zvernennia [Reports, speeches, appeals]. Kyiv: Vydavnychyi viddil Ukrainskoi Pravoslavnoi Tserkvy [in Ukrainian].

3. Chornomorets Yu. (2018). Ideal Khrystyianskoi Ukrainy yak vymoha sotsialnoho vchennia khrystyianskykh Tserkov [The ideal of Christian Ukraine as a requirement of the social doctrine of the Christian Churches]. risu.org.ua. Retrieved from http://risu.org.ua/ua/index/ expert_thought/ analytic/47555/ [in Ukrainian].

4. Chornomorets Yu. (2018). Vidpovidalnist Tserkov za maibutnie Ukrainy [Responsibility of the Churches for the future of Ukraine]. risu.org.ua. Retrieved from http://risu.org.ua/ 
ua/index/studios/materials_conferences/56445/ [in Ukrainian].

5. Khvesyk M. A., Bystriakov I. K., Levkovska L. V., Pylypiv V. V. (2012). Stalyi rozvytok: svitohliadna ideolohiia maibutnoho [Sustainable development: outlook ideology of the future]. Kyiv: Derzhavna ustanova "Instytut ekonomiky pryrodokorystuvannia ta staloho rozvytku Natsionalnoi akademii nauk Ukrainy" [in Ukrainian].

6. Holovatyi M. F. (2006). Politychna mifolohiia [Political mythology]. Kyiv: MAUP [in Ukrainian].

7. Ferents T. (Eds.). (2017). 125 dumok Patriiarkha Yosyfa Slipoho [125 views of Patriarch Yosyf Slipyi]. Lviv: Svichado [in Ukrainian].

8. Martyshyn Dionisii, protoiereus. (2013). Zustrich iz Zhyvym Bohom: dukhovni besidy na pravoslavni sviata
[Meeting with the Living God: Spiritual Conversations on Orthodox Feasts]. Kyiv: Dukhovno-prosvitnytskyi Tsentr imeni Sviatykh Apostoliv [in Ukrainian].

9. Viktor (Bed), archimandrite. (2010). Konstytutsiino-pravovi aspekty realizatsii prava liudyny na svobodu sovisti ta virovyznannia [Constitutional and legal aspects of the implementation of human rights to freedom of conscience and religion]. Uzhhorod: Informatsiino-vydavnychyi tsentr "UUBA-KaU" [in Ukrainian].

10. Martyshyn D. S. (2017). Dialoh Ukrainskoi Pravoslavnoi Tserkvy ta suspilstva u protsesi politychnykh transformatsii Ukrainy [Dialogue of the Ukrainian Orthodox Church and Society in the Process of Political Transformations in Ukraine]. Kyiv: DP "Vyd. dim "Personal” [in Ukrainian]. 